\title{
PENGARUH KONSENTRASI NaOH TERHADAP KUALITAS TEPUNG TULANG IKAN BANDENG (Chanos chanos)
}

\author{
Mubin $^{1)}$, Indri Anggreani ${ }^{1)}$, Finarti' ${ }^{1)}$, dan Alismi M. Salanggon ${ }^{1)}$ \\ ${ }^{1}$ Sekolah Tinggi Perikanan dan Kelautan Palu, \\ J1.Soekarno- Hatta KM.6, Palu Sulawesi Tengah. \\ E-mail : mubin@stplpalu.ac.id
}

\begin{abstract}
Fishbone is one form of waste from fish processing. Milkfish bone flour has high calcium and phosphorus content and can be an alternative source for the fulfillment of calcium and phosphorus in the body. The aimed of this research to find out the effect of $\mathrm{NaOH}$ concentration on the quality of milkfish bone meal (Chanos chanos). The research was conducted at the Animal Products Technology Laboratory, Tadulako University. Simultaneously, the analysis of calcium and water content was located at the Soil Science Laboratory of the Faculty of Agriculture, University of Tadulako. The length of time for the study is one month from March April 2019. The research method that will be used is an experiment with a Completely Randomized Design (CRD) with the effect of $\mathrm{NaOH}$ concentration as follows: $\mathrm{P1}: 1 \% \mathrm{NaOH}$ with a boiling temperature of $70{ }^{\circ} \mathrm{C} ; \mathrm{P} 2: 2 \% \mathrm{NaOH}$ with a boiling temperature of $70{ }^{\circ} \mathrm{C}$; $\mathrm{P3}$ : $3 \% \mathrm{NaOH}$ with a boiling temperature of $70^{\circ} \mathrm{C}$; and $\mathrm{P} 4: 4 \% \mathrm{NaOH}$ with a boiling temperature of $70^{\circ} \mathrm{C}$. The results of variance showed that it could be stated that the results of the analysis of calcium levels with the influence of $\mathrm{NaOH}$ concentration on the quality of milkfish bone meal do not have a significant effect on the value of calcium levels in fishbone meal flour.
\end{abstract}

Keywords: Fish Bones, Calcium Levels, Water Content, NaOH (Sodium Hydroxide)

\section{PENDAhULUAN}

Ikan bandeng merupakan suatu komoditas perikanan yang memiliki rasa cukup enak dan gurih sehingga banyak digemari masyarakat. Ikan bandeng digolongkan sebagai ikan berprotein tinggi dan berkadar lemak rendah.Selain itu, menyatakan bahwa volume produksi ikan bandeng pada tahun 2012 sebesar 518.939 ton, pada tahun 2013 meningkat sebesar 626.878 ton (Direktorat Jenderal Perikanan Budidaya, 2014). Produksi budidaya bandeng nasional terus naik seiring dengan usaha dari pemerintah untuk menaikkan produksi bandeng karena besarnya potensi ikan bandeng (Irianto dan Soesilo 2007).

Tulang ikan merupakan salah satu bentuk limbah dari industri pengolahan ikan yang memiliki kandungan kalsium terbanyak diantara bagian tubuh ikan, karena unsur utama dari tulang ikan adalah kalsium, fosfor dan karbonat. Kalsium merupakan salah satu mineral terpenting yang dibutuhkan oleh tubuh. Kalsium yang berasal dari hewan seperti limbah tulang ikan sampai saat ini belum banyak dimanfaatkan untuk kebutuhan manusia. Salah satu bentuk pemanfaatan ikan saat produksinya melimpah adalah diolah dalam bentuk tepung. Tepung kalsium tulang ikan adalah tepung yang terbuat dari tulang ikan yang dikeringkan dan dihancurkan hingga luluh. Tepung kalsium tulang ikan digunakan sebagai makanan hewan dan pupuk tanaman, tetapi ada pula tepung kalsium tulang ikan yang dibuat secara khusus untuk bahan makanan manusia. Tepung tulang ikan yang dibuat secara khusus ini disebut fish protein concentrate (Winarno, 2010).

Natrium hidroksida $(\mathrm{NaOH})$ atau soda kaustik, adalah sejenis basa logam kaustik, natrium hidroksida membentuk larutan alkalin yang kuat ketika dilarutkan ke dalam air. Natrium hidroksida murni berbentuk putih padat dan tersedia dalam bentuk pelet, serpihan, butiran ataupun larutan jenuh 50\%. $\mathrm{NaOH}$ bersifat lembab cair dan secara 
spontan menyerap karbondioksida dari udara bebas, sangat larut dalam air dan akan melepaskan panas ketika dilarutkan. $\mathrm{NaOH}$ juga larut dalam etanol dan metanol, walaupun kelarutan $\mathrm{NaOH}$ dalam kedua cairan ini lebih kecil daripada kelarutan $\mathrm{KOH}$. $\mathrm{NaOH}$ tidak larut dalam dietil eter dan pelarut non polar lainnya (Perry, 2000). Tujuan dilaksanakannya penelitian ini ialah untuk mengetahui pengaruh konsentrasi $\mathrm{NaOH}$ terhadap kualitas tepung tulang ikan Bandeng. Manfaat yang diharapkan dari hasil penelitian ini ialah mengetahui konsentrasi terbaik dari $\mathrm{NaOH}$ dan suhu perebusan terhadap kualitas tepung tulang ikan Bandeng.

\section{METODE PENELITIAN}

\section{Lokasi dan Waktu Penelitian}

Penelitian ini telah dilaksanakan pada bulan april sampai juni 2019. Pembuatan tepung tulang ikan bandeng (Chanos chanos) dan pengujian kadar air bertempat di Laboratorium Teknologi Hasil Ternak Univeritas Tadulako, sedangkan analisis kadar kalsium bertempat di Laboratorium Ilmu Tanah Fakultas Pertanian Universitas Tadulako.

\section{Alat dan Bahan}

Alat yang digunakan adalah aluminium foil, pisau, talenan, panci pengukus, blender, baskom, kain saring, nerasa analitik, oven,batang pengaduk, gelas ukur, thermostatic water bath, sendok dan alat yang akan digunakan analisis. Bahan baku utama yang digunakan dalam penelitian ini adalah tulang ikan bandeng. Bahan- bahan lain yang digunakan adalah aquadest $\mathrm{HCl} 1 \%$, dan $\mathrm{NaOH}$. dan bahan kimia lainnya yang digunakan untuk analisis.

\section{Rancangan Percobaan}

Penelitian ini menggunakan

Rancangan Acak Lengkap (RAL), sedangkan perlakuan yang dilakukan terdiri atas 4 perlakuan dan 3 ulangan yaitu :

P1 : $1 \% \mathrm{NaOH}$ suhu perebusan $70^{\circ} \mathrm{C}$ $\mathrm{P} 2: 2 \% \mathrm{NaOH}$ suhu perebusan $70^{\circ} \mathrm{C}$ $\mathrm{P} 3: 3 \% \mathrm{NaOH}$ suhu perebusan $70^{\circ} \mathrm{C}$ $\mathrm{P} 4$ : $4 \% \mathrm{NaOH}$ suhu perebusan $70^{\circ} \mathrm{C}$

\section{Prosedur Pembuatan Tepung Tulang Ikan Bandeng}

Prosedur pembuatan tepung tulang ikan bandeng pada penelitian ini adalah sebagai berikut:

- Tulang ikan segar dicuci bersih

- Tulang ikan direbus dengan air selama 2 jam dengan perbandingan tulang dan air $1: 3(\mathrm{~b} / \mathrm{v})$.

- Tulang ikan diangkat dan tiriskan, lalu dibersihkan dari sisa daging yang masih menempel ditulang ikan bandeng.

- Tulang dikeringkan dalam oven pada suhu $65^{\circ} \mathrm{C}$ selama \pm 10 jam.

- Tulang Ikan dihaluskan dengan menggunakan blender

- Penimbangan tepung tulang ikan bendeng masing-masing sebanyak $2 \mathrm{~g}$ untuk setiap sampel.

- Melarutkan $\mathrm{NaOH}$ dengan menggunakan aquades kemudian campurkan dengan tepung tulang ikan bandeng yang telah ditimbang.

- $\mathrm{NaOH}$ dengan Konsentrasi masingmasing $1 \%, 2 \%, 3 \%, 4 \%$ dengan suhu $70{ }^{\circ} \mathrm{C}$.

- Tulang yang telah hancur kemudian dilakukan penyaringan dengan menggunakan kain saring sampai netral \pm 2 jam.

- Tepung hasil pemisahan kemudian dikeringkan dalam oven pada suhu $100^{\circ} \mathrm{C}$ selama 4 jam.

- Tepung tulang ikan bandeng.

\section{Parameter Pengujian Kadar Kalsium Ca}

Ditimbang 2,5 g contoh tanah ukuran $>2 \mathrm{~mm}$, lalu dicampur dengan lebih kurang 5 g pasir kuarsa. Dimasukkan ke dalam tabung perkolasi yang telah dilapisi berturut-turut dengan filter pulp dan pasir terlebih dahulu (filter pulp digunakan seperlunya untuk menutup lubang pada dasar tabung, sedangkan pasir kuarsa sekitar 2,5 g) dan lapisan atas ditutup dengan penambahan 2,5 g pasir. Ketebalan setiap lapisan pada sekeliling tabung diupayakan supaya sama. Siapkan pula blanko dengan pengerjaan seperti contoh tapi tanpa contoh tanah. Kemudian diperkolasi dengan amonium acetat $\mathrm{pH} 7,0$ sebanyak $2 \times 25 \mathrm{ml}$ 
dengan selang waktu 30 menit. Filtrat ditampung dalam labu ukur $50 \mathrm{ml}$, diimpitkan dengan amonium acetat $\mathrm{pH} 7,0$ untuk pengukuran kationdd: $\mathrm{Ca}, \mathrm{Mg}, \mathrm{K}$, dan $\mathrm{Na}(\mathrm{S})$. Tabung perkolasi yang masih berisi contoh diperkolasi dengan $100 \mathrm{ml}$ etanol 96\% untuk menghilangkan kelebihan amonium dan perkolat ini dibuang. Sisa etanol dalam tabung perkolasi dibuang dengan pompa isap dari bawah tabung perkolasi atau pompa tekan dari atas tabung perkolasi. Selanjutnya diperkolasi dengan $\mathrm{NaCl} 10 \%$ sebanyak $50 \mathrm{ml}$, filtrat ditampung dalam labu ukur $50 \mathrm{ml}$ dan diimpitkan dengan larutan $\mathrm{NaCl} 10 \%$. Filtrat ini digunakan untuk pengukuran KTK dengan cara destilasi atau kolorimetri.

Pengukuran Cadd (Perkolat NH4-Ac

(S) dan deret standar campur $1 \mathrm{ml}$ ke dalam tabung reaksi, kemudian ditambahkan $9 \mathrm{ml}$ larutan $\mathrm{La} \quad 0,25 \%$ dan dikocok hingga homogen. Kemudian diukur menggunakan Flamefotometer deret serta standar sebagai pembanding.Hasil pengukura dimasukkan kedalam persamaan (1).

$$
C a_{d d}=\frac{\text { ppm kurva }}{\text { Bst Kation }} \times \frac{\text { mlekstrak }}{1000 \mathrm{ml}} \times \frac{1000 \mathrm{~g}}{\text { berat sampel }} \times 0,1 \times f p \times f k
$$

\section{Kadar Air}

Cawan porselin yang bersih dioven pada suhu $105{ }^{\circ} \mathrm{C}$ selama 1 jam kemudian dinginkan dalam desikator selama 15 menit dan ditimbang (A gram). Ditimbang dengan teliti lebih kurang 1 gram contoh ( cawan porselin + contoh $=\mathrm{B}$ gram) Masukkan sampel/contoh kedalam oven dengan hati-hati selama 8 jam atau dibiarkan bermalam. Pindahkan Sampel ke dalam desikator dan biar dingin selama kurang lebih 30 menit kemudian timbang dan catat berat (C gram). Kadar air dapat dihitung dengan menggunakan persamaan 2 .

$$
\text { Kadar air }=\frac{B-C}{B-A} \times 100 \%
$$

Keterangan :

$\mathrm{B}=$ Berat cawan dan sampel sebelum dikeringkan (g)

$\mathrm{C}=$ Berat cawan dan sampel setelah dikeringkan $(\mathrm{g})$

$\mathrm{A}=$ Berat cawan kosong

\section{Analisis Data}

Analisa data yang digunakan dalam penelitian ini adalah Rancangan Acak Lengkap (RAL) dengan perlakuan yang terdiri atas empat (4) kali dan diulang sebanyak tiga (3) kali sehingga diperoleh 12 unit percobaan. Bila hasil analisis berbeda nyata maka dilanjutkan dengan uji lanjut BNJ untuk melihat perbedaan antara perlakuan. Para meter yang diamati adalah lemak, serat, dan protein (Hanafiah, 2010), metode analisisnya persamaan 3 :

$$
\mathrm{Yij}=\alpha \mathrm{i}+\mu \mathrm{i}+\epsilon \mathrm{ij}
$$

Dimana :

Yij = Nilai pengamatan perlakuan

$\mathrm{M}=$ Rata-rata umum pengamatan

$\mathrm{A}=$ Pengaruh Perlakuan

eij $=$ Galat Percobaan

$\mathrm{I}=$ Perlakuan

$\mathrm{J}=$ Ulangan

Bila terdapat pengaruh yang nyata maka akan dilanjutkan dengan uji Beda Nyata Jujur (BNJ). Model matematisnya persamaan 4 .

$B N J_{(\alpha)}=Q_{(\alpha)}(P: d b$. galat $) \sqrt{\frac{K T G}{\text { ulangan }}}(4)$

\section{HASIL DAN PEMBAHASAN \\ Analisis Kadar Kalsium}

Pengujian kadar kalsium bertujuan untuk mengetahui jumlah kalsium yang terkandung dalam bahan tepung tulang ikan bandeng, mineral utama yang terkandung dalam tulang adalah kalsium dan fosfor, sedangkan mineral lain dalam jumlah kecil adalah natrium, magnesium, dan flour (Winarno, 2010). Hasil.untuk rerata nilai kadar kalsium dengan pengaruh perbedaan suhu perebusan dan konsentrasi $\mathrm{NaOH}$ terhadap kualitas tepung tulang ikan bandeng dapat dilihat pada Gambar 1 .

Dari Gambar 1, terlihat bahwa nilai rerata kadar kalsium dengan pengaruh perbedaan suhu perebusan dan konsentrasi $\mathrm{NaOH}$ terhadap kualitas tepung tulang ikan bandeng yang tertinggi yaitu P2 sebesar 15, $28 \%$, terendah P4 sebesar $14,41 \%$, 
sedangkan P3 sebesar $14,85 \%$, dan P1 sebesar $15,26 \%$. Dari hasil sidik ragam menunjukkan dapat dinyatakan bahwa hasil analisis kadar kalsium dengan pengaruh konsentrasi $\mathrm{NaOH}$ terhadap kualitas tepung tulang ikan bandeng, tidak memberikan pengaruh nyata terhadap nilai kadar kalsium .hal ini dikarenakan sifat dari $\mathrm{NaOH}$ yang dapat mengikat panas sehingga terjadi peleburan pada kadar kalsium yang terdapat pada tepung tulang ikan bandeng.

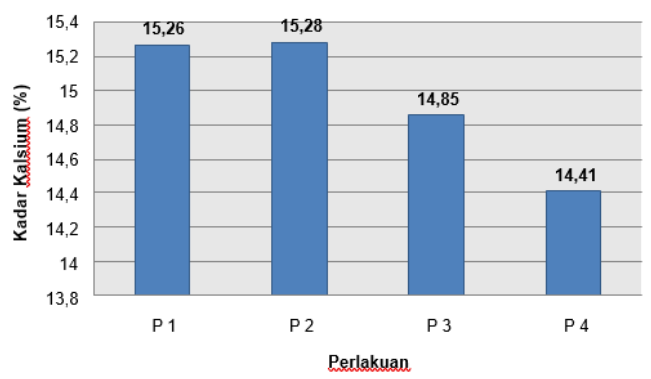

Gambar 1. Rerata nilai kadar kalsium

\section{Analisis Kadar Air}

Hasil penelitian kadar air dan sidik ragam tepung tulang ikan bendeng dengan konsentrasi $\mathrm{NaOH}$ dapat dilihat pada Gambar 2.

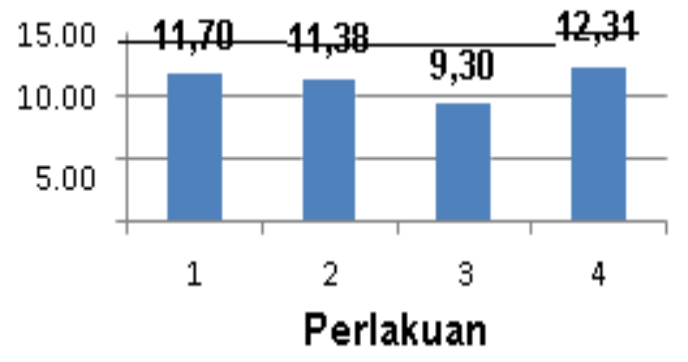

Gambar 2. Rerata nilai kadar air

Dari hasil analisis sidik ragam menunjukkan bahwa penggunaan $\mathrm{NaOH}$ mempengaruhi kualitas tepung tulang ikan bandeng. Rerata nilai kadar air yang diperoleh akibat perlakuan dapat dilihat pada Tabel 1 yang menunjukkan pada perlakuan P4 (12,31) merupakan nilai tertinggi dan mengalami penurunan nilai pada perlakuan P3 $(11,70)$ dan diikuti pada perlakuan P2 $(11,38)$ selanjutnya perlakuan P1 $(9,38)$ adalah nilai terendah.
Tabel 1. Rerata Nilai Kadar Air dengan Pengaruh Konsentrasi $\mathrm{NaOH}$ pada Kualitas Tepung Tulang Ikan Bandeng

\begin{tabular}{lcccc}
\hline Perlakuan & P4 & P3 & P2 & P1 \\
\hline Rerata & $12,31^{\mathrm{a}}$ & $11,70^{\mathrm{b}}$ & $11,38^{\mathrm{b}}$ & $9,30^{\mathrm{c}}$ \\
\hline Keterangan : & $\begin{array}{l}\text { Perlakuan yang tidak diikuti oleh huruf } \\
\text { yang sama berarti memberikan } \\
\text { pengaruh nyata menurut BNJ 5\% }\end{array}$ &
\end{tabular}

Tabel 1 menunjukkan hasil analisis ragam terhadap kadar air dengan pengaruh konsentrasi $\mathrm{NaOH}$ terhadap kualitas tepung tulang ikan bandeng memberikan pengaruh yang nyata yang berarti terdapat perbedaan kadar air yang sangat nyata kerena pengaruh perlakuan, nilai ini masih berada pada kisaran standar yang ditetapkan SNI (SNI 01-3158-1992) untuk kadar air tepung tulang (maksimal $8 \%$ ), hal ini disebabkan karena sifat kimia $\mathrm{NaOH}$ yang sangat larut dalam air dan memiliki kelembabpan yang tinggi sehingga perbedaan kadar air yang diperoleh sangat dipengaruhi oleh metode pembuatan tepung dan teknik pengeringan tulang serta jenis ikan yang digunakan.

\section{KESIMPULAN}

Berdasarkan hasil penelitian dapat disimpulkan bahwa analisis kadar kalsium dengan konsentrasi $\mathrm{NaOH}$ yang terhadap pada kualitas tepung tulang ikan bandeng, tidak memberikan pengaruh nyata terhadap nilai kadar kalsium. Analisis kadar air pada tepung ikan bandeng dengan konsentrasi $\mathrm{NaOH}$ berpengaruh sangat nyta terhadap analisis kadar air pada tepung tulang ikan bandeng. Berdasarkan hasil penelitian yang dilakukan, disarankan untuk melakukan penelitian lanjutan tentang penetapan suhu perebusan terbaik terhadap tepung tulang ikan bandeng.

\section{REFERENSI}

Direktur Jenderal Perikanan Budidaya. 2014. Hasil Data Perikanan Budidaya Ikan Bandeng. Kementrian Kelautan dan Perikanan Republik Indonesia. Jakarta. 
KAUDERNI : Journal of Fisheries, Marine and Aquatic Science

https://jurnal.stplpalu.ac.id/index.php/kauderni/index

Volume 2, Nomor 2, (2020)

ISSN 2541-0571

https://doi.org/10.47384/kauderni.v2i2.51

Irianto, H.E. dan I, Soesilo. 2007. Dukungan

Teknologi Penyediaan Produk

Perikanan. Badan Riset Kelautan dan Perikanan Departemen Kelautan Dan

Perikanan. Makalah Seminar

Nasional Hari Pangan Sedunia 2007.

Perry, R.H. 2000. "Perry's Chemical

Engineers Hand Book", 6th. ed. Mc.

Graw Hill Co., International Student edition, Kogakusha, Tokyo.

Winarno, F.G. 2010. Kimia Pangan dan Gizi. Penerbit PT. Gramedia Pustaka Utama. Jakarta. 
KAUDERNI : Journal of Fisheries, Marine and Aquatic Science https://jurnal.stplpalu.ac.id/index.php/kauderni/index

Volume 2, Nomor 2, (2020)

ISSN 2541-0571

https://doi.org/10.47384/kauderni.v2i2.51 